\title{
Differential glucocorticoid effects on proliferation and invasion of human trophoblast cell lines
}

\author{
M Mandl ${ }^{1,2}$, N Ghaffari-Tabrizi ${ }^{1}$, J Haas ${ }^{1}$, G Nöhammer ${ }^{2}$ and G Desoye ${ }^{1}$ \\ ${ }^{1}$ Clinic of Obstetrics and Gynaecology, Medical-University of Graz, Auenbruggerplatz 14, A-8036, Graz, Austria and \\ ${ }^{2}$ Institute of Molecular Biosciences, Karl-Franzens-University, Graz, Austria \\ Correspondence should be addressed to G Desoye; Email: gernot.desoye@meduni-graz.at
}

\begin{abstract}
Several clinical situations require continuous glucocorticoid (GC) treatment during pregnancy. A well-known deleterious side effect of such treatment is the higher incidence of growth-restricted fetuses, for which a too shallow trophoblast invasion is presently hypothesised as the underlying cause. This study investigated whether the synthetic GC triamcinolone acetonide (TA) influences proliferation, invasion and endocrine activity of human trophoblast. BeWo and JEG-3 choriocarcinoma cell lines both express GC receptors (western blotting) and were used as models for human trophoblast. JAR devoid cells of GC receptor were used as negative control. The cells were cultured for $48 \mathrm{~h}$ without (control) or with $0.5,5$ and $50 \mu \mathrm{M}$ TA. In the presence and absence of serum, proliferation was determined by cell counting and measuring the cell cycle regulating protein cyclin B1 (Western blotting); invasion was determined by a conventional Matrigel invasion assay and by measuring the secretion (ELISA) of matrix-metalloproteinases (MMP-2, MMP-9) into the culture medium; endocrine activity was assessed by measuring the levels of human chorionic gonadotropin (ELISA) into the culture medium. TA altered the number of viable and dead cells as well as cyclin B1 levels and, to a lesser extent, invasion of BeWo and JEG-3, with a strong influence of serum. BeWo and JEG-3 cells reacted differently and in most instances reverse. In the cell lines used as models of human trophoblast, TA alter some functions relevant to proliferation and invasion, and suggest that caution should be exercised when treating women with GCs during pregnancy.

Reproduction (2006) 132 159-167
\end{abstract}

\section{Introduction}

In late human pregnancy, glucocorticoids (GC) play an important role in the preparation for birth, including involvement in lung and cardiac development of the fetus. Antenatal short-term corticosteroid therapy results in reduction of fetal mortality, respiratory distress syndrome and intraventricular haemorrhage in preterm babies (Sloboda et al. 2005). These benefits extend to a broad range of gestational age.

However, several clinical situations like asthma, allografts and systemic lupus erythematosus require continuous GC treatment throughout the gestational period (Ostensen 2001). A well-known deleterious side effect of GC treatment during pregnancy is the higher incidence of growth-restricted fetuses (Reinisch et al. 1978, Garvey \& Scott 1981, Katz et al. 1990, Edwards et al. 1993, Seckl 1994) and an intrauterine programming of cardiovascular, metabolic and neuroendocrine disorders in adult life (Seckl 2004). We recently identified a downregulation of trophoblast glucose transporters by GC and hypothesised that this may contribute to the restricted fetal and placental growth observed with the GC treatment (Hahn et al. 1999). The pathogenesis of fetal growth restriction in the absence of GC treatment is more complex and the current consensus implicates too shallow trophoblast invasion into the maternal decidua in the first trimester of pregnancy as the underlying cause. Therefore, it is tempting to hypothesise that GC may affect trophoblast invasion. Moreover, the number of invasive trophoblast is closely linked to trophoblast proliferation, which determines the number of cells available for differentiation into an invasive phenotype. GC effects on trophoblast proliferation may also explain the correlation of maternal GC levels with the placental weight (Edwards et al. 1993), suggesting that the placenta can respond to maternal GC in vivo. In fact, high affinity, low capacity GC receptors have been identified in the human placenta (Speeg \& Harrison 1979, Lageson et al. 1983, Robinson et al. 1988, Hahn et al. 1999). 
Physiological cortisol levels in maternal plasma during human pregnancy are in the range of $1 \mu \mathrm{mol} / \mathrm{l}$ (Simmer et al. 1974), which is about 5-10 times higher than those in the fetus (Edwards et al. 1993). The majority of the circulating cortisol in the human fetuses is derived only relatively late during gestation from the fetal adrenal gland and not from maternal sources (Pasqualini et al. 1970). Transplacental transfer of maternal cortisol is limited because of the protective action of the enzyme $11 \beta$ hydroxysteroid dehydrogenase (11 $\beta-$ HSD-2) (Krozowski etal. 1995). This enzyme is expressed in increasing amount throughout gestation in the placenta (Schoof et al. 2001), and predominantly in the trophoblast (Driver etal. 2001) as well as in many other fetal tissues (Stewart et al. 1994, Brown et al. 1996). It catalyses the conversion of active cortisol into inert cortisone (Albiston et al. 1994, Stewart et al. 1994). The physiological role of $11 \beta-H S D-2$ is to protect the mineralocorticoid receptor from activation by cortisol, which binds to the receptor with the same affinity as aldosterone (Arriza et al. 1987).

Synthetic GCs such as dexamethasone, however, are significantly less metabolised by $11 \beta-$ HSD-2 than cortisol (Brown et al. 1996, Diederich et al. 1997). Therefore, these synthetic GCs readily cross the placenta. It is known that prenatal GC exposure reduces the birth weight in humans (Seckl 1994), and even small doses of dexamethasone given prenatally alter neuropsychological parameters such as emotionality (Trautman et al. 1995, Lajic et al. 1998).

The study investigated whether a synthetic GC influences proliferation and invasion of human trophoblast. The choriocarcinoma cell lines BeWo and JEG-3, both expressing GC receptors, have been used. In addition, JAR cells were employed as a negative control because they lack the GC receptors. The experiments were performed both in the absence and presence of fetal calf serum (FCS) to determine if serum influences the GC effects.

The synthetic GC triamcinolone-acetonide (TA) was used. It (1) specifically binds to the GC receptor in placental cytosol (Speeg \& Harrison 1979) with higher affinity than dexamethasone (Dancis et al. 1980), which is also used for experimental studies into GC action, (2) is not inactivated by $11 \beta-H S D-2$ (Feinstein \& Schleimer 1999), and (3) has proven to be effective in altering the placental function (Hahn et al. 1994, 1999).

Proliferation was determined by cell counting and measuring the expression level of cyclin B1, a cell cycle regulating molecule with peak expression at the $\mathrm{G} 2 / \mathrm{M}$ interface. It has proven to be useful in determining the trophoblast mitotic activity (Genbacev et al. 1997). Invasion was assessed by a conventional Matrigel invasion assay and by measuring the amount of MMP2 and MMP-9 secreted into the culture medium. Both play a key function in the trophoblast invasion (Staun-Ram et al. 2004). Because antenatal dexamethasone administration is associated, among other adverse effects, with reduced placental hormone production (reviewed by Ogueh \& Johnson 2000), measurements of potential TA effects on the secretion of human chorionic-gonadotropin- $\beta$ (hCG- $\beta$ ) were included in the study.

\section{Material and Methods}

\section{Cell culture}

BeWo (CCL-98, American Type Culture Collection (ATCC) passage number, 191), JAR (HTB-144, ATCC passage number, 722) and JEG-3 (HTB-36, ATCC passage number, 124) choriocarcinoma cells were obtained from the (ATCC, Rockville, MD, USA). All cells were used up to ten in-house passages. The JAR and JEG-3 cells were cultured in Dulbecco's modified Eagle medium (Gibco), containing 10\% FCS (HyClone Laboratories, Logan, UT, USA) and $1 \%$ penicillin/streptomycin (Gibco), whereas BeWo cells were cultured in F-12 medium (Gibco) supplemented with 10\% FCS, 1\% penicillin/streptomycin and $2 \mathrm{mmol} / \mathrm{l}$ L-Gln (Gibco).

The cells were plated in six-well plates (Falcon Multiwell Cell Culture Plates, Becton Dickinson, NJ, USA) at a density of $4 \times 10^{4}$ (JAR, JEG-3) and $6 \times 10^{4}$ cells (BeWo) per well, and cultured for $24 \mathrm{~h}$ with FCS under a humidified $5 \% \mathrm{CO}_{2} / 95 \%$ air atmosphere at $37^{\circ} \mathrm{C}$. After this time, cells were incubated in the respective medium supplemented with $0.5,5$ and $50 \mu \mathrm{M}$ triamcinolone acetonide (TA) (Volon A, Bristol-Myers Squibb, Vienna, Austria) dissolved in benzylalcohol in the presence and absence of $10 \%$ FCS for $48 \mathrm{~h}$. After $48 \mathrm{~h}$, all cultures were still subconfluent (-FCS, 50\%, +FCS, 80-90\%), but extension of the culture period to $72 \mathrm{~h}$ had resulted in partial confluence (pilot experiments).

\section{Determination of hCG- $\beta$}

The amount of hCG- $\beta$ secreted into the culture media was measured by an enzyme-immunoassay (Behring Diagnostics, Inc., Westwood, MA, USA), with intra- and interassay coefficients of variation of 6.4 and $9.2 \%$ respectively. Assay sensitivity was $1 \mathrm{mlU} / \mathrm{ml}$.

\section{Determination of cell number}

A direct cell counting method was used. Cells were cultured under the conditions defined above. After $48 \mathrm{~h}$, cells were detached by Accutase (Innovative Cell Technologies, Inc., San Diego, CA, USA) and cell aggregates dissociated by Accumax (Innovative Cell Technologies, Inc.). The number of cells was counted in the cell counter and analyser system CASY 1 (Schärfe System, Reutlingen, Germany) using a 150$\mu \mathrm{m}$ capillary. Measurements with this system are based on the detection of changes in conductivity along an aperture during the flow of a cell-containing liquid. 
The result is a size-distribution curve of the cells (Falkenhain et al. 1998), in which cell debris, dead and viable cells can be identified by their distinct diameters. This method has been recently used to demonstrate the effects of hyperglycaemia on choriocarcinoma cells (Weiss et al. 2001).

\section{Immunoblotting of GC receptor and cyclin B1 protein}

Cells were lysed in buffer containing $0.01 \mathrm{~mol} / \mathrm{l}$ Tris $(\mathrm{pH}$ 7.4), $1 \%$ SDS, $1 \mathrm{mmol} / \mathrm{l}$ Na-orthovanadate and complete protease inhibitor (Roche) mixed with an equal volume of Laemmli sample buffer (Sigma). Proteins $(40 \mu \mathrm{g})$ of adherent cells were subjected to SDS-PAGE and immunoblotting as described (Weiss et al. 2001). The blotting membranes were incubated (overnight, $4{ }^{\circ} \mathrm{C}$ ) with either a polyclonal anti-GC receptor antibody (1:500; P-20 Santa Cruz; Santa Cruz, CA) or a monoclonal anti-cyclin B1 antibody (1:500; Pharmingen, San Diego, CA). Anti-mouse IgG $(\mathrm{H}+\mathrm{L})$ horseradish peroxidase conjugate $(1: 1500$; Southern Biotechnology Associates, Birmingham, AL, USA) was used as the secondary antibody. The immunolabelling was visualised using the chemiluminescense-based SuperSignal CL-HRP Substrate System (Pierce, Rockford, IL, USA). The high-performance chemiluminescence film, Hyperfilm ECL (Amersham) was developed and analysed by the ONE-Dscan program (Scanalytics, Billerica, MA, USA).

\section{Matrigel invasion assay}

Details of the assay were described by Cervar et al. (1996). Briefly, the cells were incubated overnight in the presence of $\left.10 \mu \mathrm{Ci} / \mathrm{ml}^{3} \mathrm{H}\right]$-thymidine (Amersham) in medium containing 10\% FCS. Matrigel-coated (Biocoat, Becton Dickinson, Heidelberg, Germany) porous filters ( $8 \mu \mathrm{m}$ pore size) were used as a barrier in a Boyden chamber (Albini et al. 1987) to test invasion of the cells. A total of $5 \times 10^{4}$ radiolabelled cells was added to the inside of the inserts and incubated for $48 \mathrm{~h}$ at $37^{\circ} \mathrm{C}, 5 \%$ $\mathrm{CO}_{2}$ atmosphere. TA at concentrations as above were added to the medium. The invasion index represents the proportion of cells that had invaded and traversed the extracellular matrix and was calculated as the amount of radioactivity in the lower wells expressed relative to the total radioactivity in upper and lower wells (Graham et al. 1993).

\section{Determination of proMMP-2 and proMMP-9 levels}

ProMMP-2 and proMMP-9 levels were measured in all cell culture supernatants by ELISA (Biotrak, Amersham) following the instructions of the manufacturer. They measured the precursor of MMP-2 (proMMP-2), i.e. free proMMP-2 and that complexed with TIMP-2, but not the active form of MMP-2 (Fujimoto et al. 1993) and proMMP-9 (free and complexed to TIMP 1; not active MMP-9; Fujimoto et al. 1994). The range of detection for proMMP-2 is $1.5-24 \mathrm{ng} / \mathrm{ml}$ (sensitivity of $0.37 \mathrm{ng} / \mathrm{ml}$ ) and for proMMP-9 1-32 ng/ml (sensitivity of $0.6 \mathrm{ng} / \mathrm{ml}$ ).

\section{Statistical analysis}

The data expressed as mean \pm s.D. were analysed with standard methods for descriptive values and with multifactor ANOVA to compare the size of the effect. Significant overall results were further examined with Dunett's post hoc test for comparison with the control and least significant difference tests (LSD) for all other pairwise comparisons. A significance level of 0.05 was used for all the tests. For all calculations, SPSS (SPSS, Chicago, IL, USA) was used.

\section{Results \\ GC receptor expression}

Bewo and JEG-3 cells expressed GC receptors, as identified by western blotting, whereas JAR cells did not (Fig. 1). The single band detected in the western blots corresponded to the molecular mass of about $85 \mathrm{kDa}$, which is similar to the molecular mass of the human GC receptor (UniProt entry name, GCR_HUMAN; accession number, P04150).

\section{Effects on secretion of $h C G-\beta$}

All three cell lines secreted varying levels of hCG- $\beta$ with BeWo $>$ JAR $>$ JEG-3 (not shown). In the absence of FCS, TA did not affect hCG- $\beta$ production in any of the three cell lines. In the presence of serum, elevated $(P<0.05$, ANOVA) hCG- $\beta$ levels were found in JEG-3 with a peak increase of $+147 \%(P<0.05)$ at a concentration of $5 \mu \mathrm{M}$ TA (Fig. 2).

\section{Effects on proliferation and cyclin B1}

In the absence of serum, cell counts of BeWo cells decreased $(P<0.01$, ANOVA) when the cells were cultured with $0.5 \mu \mathrm{M}$ TA $(14 \%, P<0.05)$ and $5 \mu \mathrm{M}$ TA $(20 \%, P<0.01)$, whereas those of JEG-3 cells increased $(P<0.05$, ANOVA $)$ by about $24 \%(P<0.01)$ when the cells were cultured with $50 \mu \mathrm{M}$ TA. In the presence of FCS, the effects, if any, were reverted, i.e. TA increased the cell number in BeWo $(P<0.05$, ANOVA) by $46 \%(P<$ $0.001)$ at $50 \mu \mathrm{M}$, and, reduced the cell number in JEG-3 $(37 \%, P<0.01)$, at 0.5 and $5 \mu \mathrm{M}$. The latter effect was abolished by $50 \mu \mathrm{M}$ TA. The GC receptor-negative JAR cells were not affected by the presence of TA in FCS (Fig. 3). In the presence of FCS, the number of dead BeWo and JEG-3 cells increased in a dose-dependent manner 


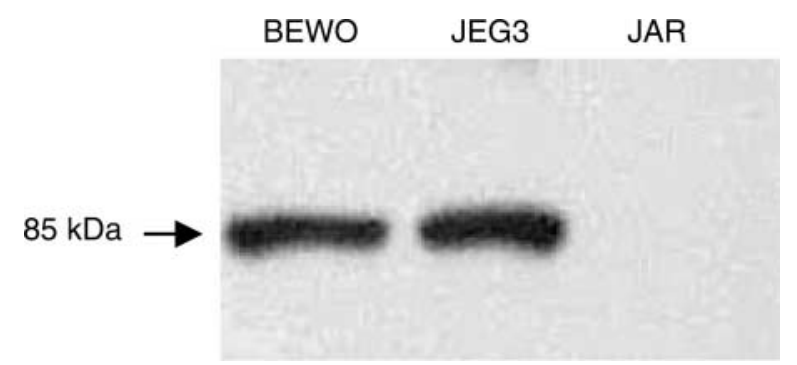

Figure 1 Detection of glucocoticoid receptor in cell lysates. Western blotting showed the presence of glucocorticoid receptors in BeWo and JEG-3 and its absence in JAR choriocarcinoma cells that were used as models for first trimester human trophoblast.

$(P<0.05$, ANOVA $)$ when TA was added. This effect was not found in the absence of FCS (data not shown).

To gain insight into TA effects on the cell cycle, cyclin B1 levels were measured. In the absence of serum, cyclin B1 expression levels decreased $(P<0.05$, ANOVA) in BeWo cells reaching a maximum of $80 \%$ at
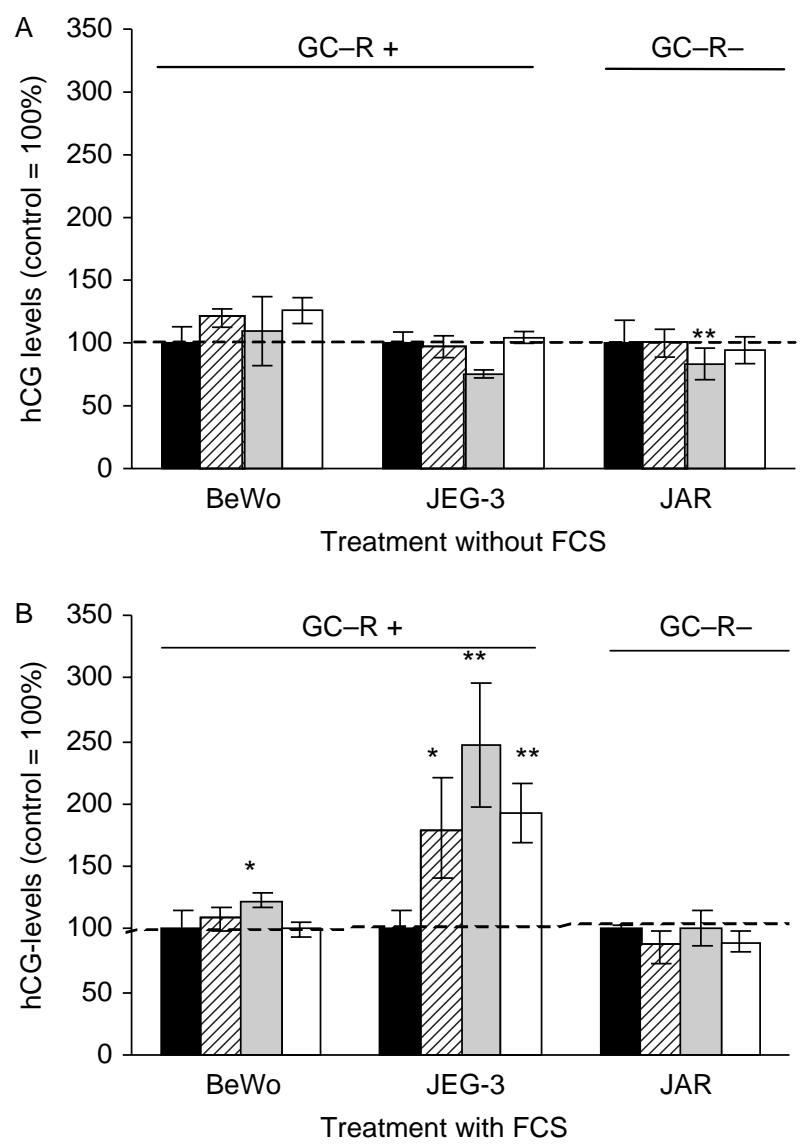

Figure 2 Effects of TA on hCG- $\beta$ secretion after $48 \mathrm{~h}$ in absence or presence of FCS. TA $(5 \mu \mathrm{M})$ decreased hCG- $\beta$ secretion of JAR cells by about $25 \%(P<0.01$, panel A). In the presence of FCS (panel B) TA led to more hCG- $\beta$ in the culture medium of BeWo cells $(+23 \%)$ and of JEG-3 $(+147 \%)(P<0.05)$ at a concentration of $5 \mu \mathrm{M}$. Data (mean \pm S.D.) are expressed relative to untreated control $(=100 \%) .{ }^{*} P<0.05$; ${ }^{* *} P<0.01$ vs control. Control, TA 0.5, TA 5, TA $50 \mu \mathrm{M}$.
$50 \mu \mathrm{M}$ TA $(P<0.01)$. The presence of FCS reverted this effect, i.e. TA induced an increase $(P<0.05$, ANOVA) in cyclin B1 levels ( $70 \%$ at $50 \mu \mathrm{M}, P<0.01$ ). In JEG-3 cells, a non-significant trend towards increasing $(-F C S)$ or decreasing (+FCS) cyclin B1 levels was noted that paralleled the effects on the cell number. Cyclin B1 levels in JAR were not affected (ANOVA) significantly (Fig. 4).

\section{Effects on Matrigel invasion and on secretion of proMMP-2 and proMMP-9}

In the BeWo cells, $50 \mu \mathrm{M}$ TA produced a stimulatory effect on invasion by 27 and $37 \%(P<0.05)$ in the presence and absence of FCS respectively. Invasion of JEG-3 cells was reduced by $50 \mu \mathrm{M}$ TA under both conditions by about $20 \%$, but only in the presence of FCS the effect reached significance $(P<0.05)$. Invasion of JAR cells did not respond to TA administration (Fig. 5).

In all the three cell lines, proMMP-9 levels in the culture supernatants were below the sensitivity of the
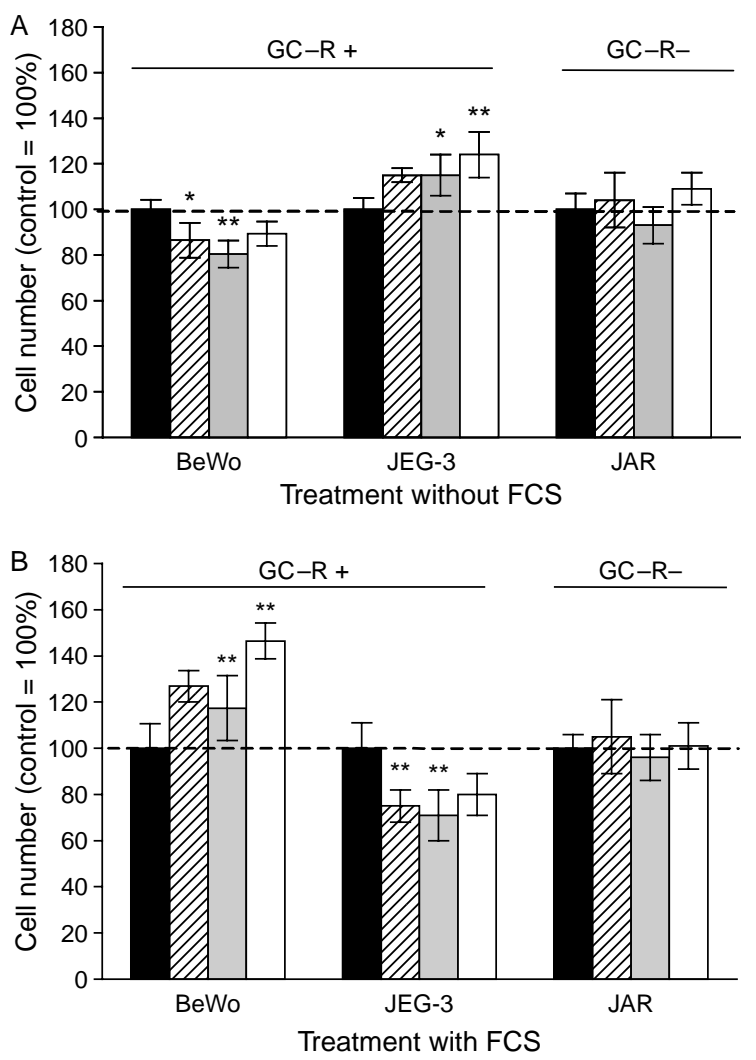

Figure 3 Effects of TA on cell number after $48 \mathrm{~h}$ in the absence and presence of FCS. BeWo, JAR and JEG-3 cells were cultured in serumfree medium (panel A) containing $0.5,5$ and $50 \mu \mathrm{M}$ of TA. A stimulatory effect of $50 \mu \mathrm{M}$ TA was found in JEG-3 (-FCS) and BeWo + FCS) cells with maximum effects of $24(P<0.01)$ and $46 \%(P>0.01)$ respectively. The cell number decreased at the lower TA doses in BeWo (-FCS) and JEG-3 (+FCS). This effect was abolished at a concentration of $50 \mu \mathrm{M}$. Data represent the mean ( \pm s.D.) of quadruplicate samples and are expressed relatively to untreated control $(=100 \%)$. ${ }^{*} P<0.05$, ${ }^{* *} P<0.01$ vs control. Control, TA 0.5, TA 5, TA $50 \mu \mathrm{M}$. 

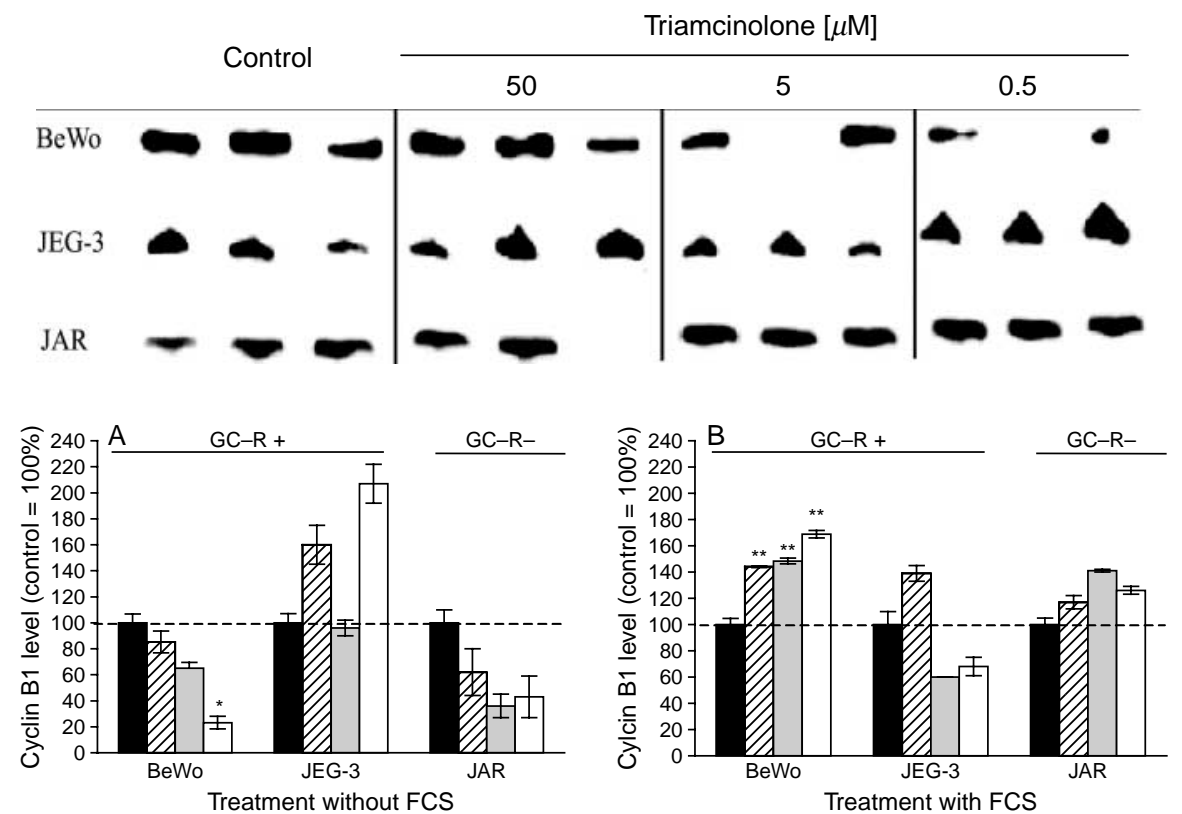

Figure 4 Immunoblots of cyclin B1 after 48-h culture (top panel). Representative experiments of BeWo, JAR and JEG-3 cells incubated with TA $(0.5,5$ and $50 \mu \mathrm{M})$ in serum-free medium are shown. Note that levels cannot be compared between cell lines. Effects of TA on cyclin B1 protein after $48 \mathrm{~h}$ in the absence and presence of FCS (bottom panel). Incubation with $50 \mu \mathrm{M}$ TA without FCS (panel A) led to a decrease of cyclin B1 protein levels in BeWo cells $(-80 \%, P<0.05)$ and increase in JEG-3 cells $(107 \%, P=0.05)$. In FCS presence (panel B) cyclin B1 levels increased in BeWo cells by $70 \%(P<0.001)$. Results represents mean \pm s.E.M. of triplicate samples and are expressed relative to control $(=100 \%)$. ${ }^{*} P<0.05,{ }^{* *} P<0.01$ vs control. Control, TA 0.5, TA 5, TA $50 \mu \mathrm{M}$. assay. ProMMP-2 was detectable only in the supernatant of BeWo and JAR cells. BeWo cells produced about ninefold more proMMP-2 than JAR cells cultured in serum-free medium. In both cell lines, addition of FCS increased proMMP-2 secretion by about threefold. In the absence of FCS, the TA treatment led to an increase $(P<0.01$, ANOVA $)$ in proMMP-2 levels in BeWo and JAR cells (Table 1 ).

\section{Summary of results}

BeWo cells responded best to TA (Table 1). Although it did not alter the hCG- $\beta$ secretion, it profoundly changed cell proliferation. In the absence of FCS, proliferation was reduced, whereas cell number and cyclin B1 levels increased in the presence of FCS, as reflected. Invasion was only stimulated by $50 \mu \mathrm{M}$ TA, regardless of the absence or presence of serum. TA only increased the proMMP-2 secretion in the absence FCS.

JEG-3 cells responded better in the presence of FCS than in its absence. TA increased hCG levels only in the presence of FCS. The cell number was higher after TA treatment, which was paralleled by a tendency to higher cyclin B1 expression levels (not significant) in the absence of FCS. Upon addition of FCS, these effects were reversed. Invasion was reduced under both conditions, but was significant only in the presence of FCS.

JAR cells, which lack the GC receptor, did not respond to TA treatment, apart from the increase in proMMP-2 levels in the absence of FCS.

\section{Discussion}

The effects of GC treatment on the fetus have received considerable interest (reviewed Seckl 1997), but less is known about the effects of GC on human placenta and trophoblast cells. The aim of this study was to investigate the effects of TA, a synthetic GC, on proliferation and invasion of three choriocarcinoma cell lines. BeWo, JEG-3 and JAR are models of trophoblasts, which secrete the major placental peptide hormone hCG (Hochberger et al. 1991, Taylor et al. 1991 Mauschitz et al. 2000). They differ in their proliferative activity and degree of differentiation. All three cell lines show invasive behaviour in invasion assays (Graham et al. 1994, Grummer et al. 1994).

GC and mineralocorticoid receptors (Driver et al. 2001) have been identified in the human placenta, in particular in the trophoblast (Lageson et al. 1983, Driver et al. 2001). Because these choriocarcinoma cells are well known for their potential of phenotypic drifts during passage in culture, it was necessary to confirm earlier data (Speeg \& Harrison 1979) using a different technique. Two of the choriocharcinoma cell lines (BeWo and JEG) express GC receptor, whereas no detectable levels of GC receptor were identified in the JAR cells. Moreover, 11 $\beta-$ HSD-2 activity (Gomez-Sanchez et al. 1996) and functional mineralocorticoid receptors (Listwak et al. 1996) were identified in JEG-3 cells. JAR cells were used as negative control in this study to identify a potential involvement of the mineralocorticoid receptor in GC effects, because GCs can also transactivate this receptor (Grossmann et al. 2004). The absence of major GC effects on JAR cells is in line with the absence of GC receptors in this particular choriocarcinoma cell line. The TA-induced proMMP-2 secretion may be the result of mineralocorticoid receptor activation, although conclusive information is pending. 

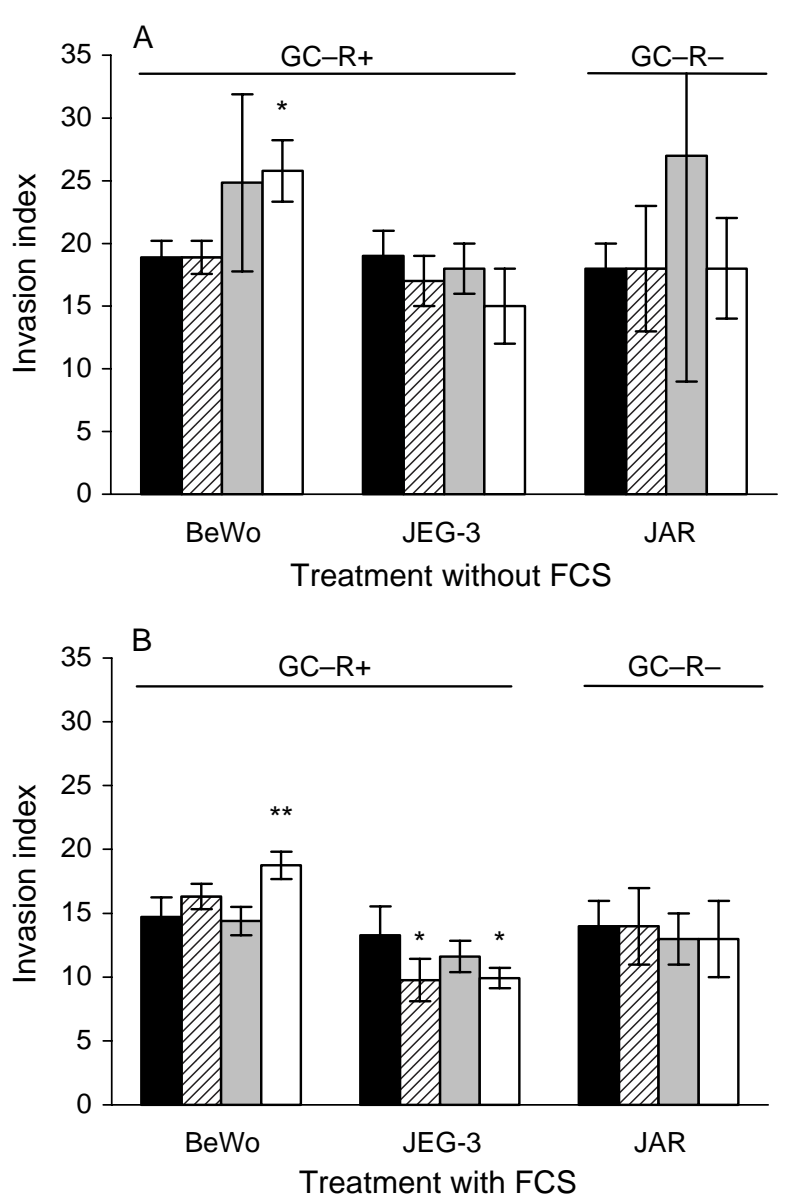

Figure 5 Effect of TA on invasion into Matrigel after $48 \mathrm{~h}$ in the absence and presence of FCS. TA stimulated invasion in a dose-dependent manner in BeWo cells $(P<0.05$, panel $A)$, the decreasing effect on JEG-3 cells was not significant. In FCS presence (panel B) $50 \mu \mathrm{M}$ TA increased invasion of BeWo cells $(27 \%, P<0.01)$ and decreased invasion of JEG-3 cells $(23 \%, P<0.05)$. Data represent the invasion index (mean \pm s.D.) of quadruplicate wells. ${ }^{*} P<0.05,{ }^{* *} P<0.01$ vs control. Control, TA 0.5, TA 5, TA $50 \mu \mathrm{M}$.

The TA doses were chosen because they have previously resulted in dose-dependent effects on term trophoblast hCG- $\beta$ and GLUT1 levels (Hahn et al. 1999). The lowest TA dose $(0.5 \mu \mathrm{M})$ corresponds to the TA concentration in blood resulting after injection of $40 \mathrm{mg}$ $\mathrm{TA}$, a dose recommended by the manufacturer for therapy in humans (Mollmann et al. 1986).
GC treatment stimulated the hCG secretion of human placental trophoblasts (Ringler et al. 1989, Hahn et al. 1999) and a transcriptional activation of hCG- $\beta$ gene by GC was suggested. In JEG-3 cells TA also stimulated hCG- $\beta$ secretion in FCS presence. The effects were significant at a concentration of $5 \mu \mathrm{M}$ and became smaller, hence insignificant, upon addition of $50 \mu \mathrm{M}$ TA. It was reported that dexamethasone up-regulated blood cell GR-mRNA levels at a concentration of $10 \mathrm{nM}$, whereas incubation with $10 \mu \mathrm{M}$ resulted in toxic effects on blood cells with a decreased amount of total mRNA samples (Vedder et al. 1999). This could be an explanation for the bimodal effect of TA not only on hCG- $\beta$ secretion, but also on proliferation and proMMP-2 secretion, since TA increased the number of dead JEG-3 cells.

Cell proliferation was determined by direct cell counting. The classical thymidine incorporation method was not a suitable option here, because thymidine kinase, the rate-limiting enzyme, is regulated by GCs (Osborne et al. 1979). TA effects on proliferation of BeWo and JEG-3 cells were converse and showed a strong influence of serum. In both cell lines the direction of the effects was reversed upon addition of serum, i.e. a TA-induced stimulation become an inhibition and vice versa. In BeWo cells these changes were paralleled by changes in cyclin B1 expression levels. Moreover, when BeWo and JEG-3 cells were cultured in FCS presence the number of dead cells increased suggesting some toxic effect of TA, which can also induce apoptosis (Schmidt et al. 2004). The parallel increase in the number of both viable and dead cells in BeWo may be attributable to the polyclonic nature of the carcinoma cells, and hence, reflect a different response of different BeWo subclones. In FCS absence the opposite effect was observed.

Cyclins and cyclin-dependent kinases (cdks) are subunits of cell cycle dependent protein kinases that regulate key events during the progression of the cell cycle (reviewed in Sanchez \& Dynlacht 2005). Cyclins are selectively expressed in different phases of the cell cycle. Cyclin B1 is a mitotic cyclin, its expression is normally low in $\mathrm{G}_{0} / \mathrm{G}_{1}$, increases in $\mathrm{S}$ and is maximal during $\mathrm{G}_{2} / \mathrm{M}$. Cyclin $\mathrm{B} 1$ is rapidly degraded at the end of mitosis, and is required for cells to enter and exit mitosis. In JEG-3 cells changes in cell count and cyclin B1 levels did not correlate. A reason could be that cyclin B1

Table 1 ProMMP-2 (ng/106 cells; mean \pm s.D.) levels in culture medium of BeWo and JAR cells after 48-h incubation without (control) or with TA.

\begin{tabular}{|c|c|c|c|c|c|}
\hline & \multirow[b]{2}{*}{ TA concentration $(\mu \mathrm{M})$} & \multicolumn{2}{|c|}{ BeWoGC-R+ } & \multicolumn{2}{|c|}{ JARGC-R - } \\
\hline & & $-\mathrm{FCS}$ & $+\mathrm{FCS}$ & $-\mathrm{FCS}$ & $+\mathrm{FCS}$ \\
\hline Control & & $414 \pm 16$ & $1164 \pm 139+$ & $47 \pm 2$ & $154 \pm 9+$ \\
\hline \multirow[t]{3}{*}{ TA } & $0.5(\mu \mathrm{M})$ & $592 \pm 51 *$ & $1229 \pm 67 \dagger$ & $55 \pm 3 *$ & $136 \pm 23 t$ \\
\hline & $5(\mu \mathrm{M})$ & $682 \pm 50^{*}$ & $1601 \pm 184^{*}+$ & $53 \pm 0^{*}$ & $135 \pm 14 \dagger$ \\
\hline & $50(\mu \mathrm{M})$ & $958 \pm 59 *$ & $1110 \pm 58 \dagger$ & $82 \pm 1 *$ & $133 \pm 14 t$ \\
\hline
\end{tabular}

$* P<0.01$ vs control. $+P<0.01$ vs FCS. 
changes precede changes in cell number, which would have been identified by a time course analysis over a longer culture period. Alternatively, a block at the $\mathrm{G}_{0} / \mathrm{G}_{1}$ transition does not allow cells to complete the cell cycle (JEG-3; + FCS). Without further detailed measurements of other cell cycle regulating proteins and a cell cycle analysis the underlying mechanism cannot be identified.

All three cell lines invade into extracellular matrix (Graham et al. 1994, Grummer et al. 1994, present study), because of their ability to secrete matrix metalloproteinases (Fisher et al. 1989, Bischof et al. 1995). Among these, MMP-2 and MMP-9 are involved in trophoblast invasion into the extracellular matrix of maternal decidua.

BeWo and JEG-3 cell invasion responded differently to TA treatment; in BeWo the highest TA dose induced invasion, whereas reduced it in JEG-3 cells similar to cytotrophoblasts (Librach et al. 1994, Morrish et al. 1998). Synthetic GCs inhibit MMP production (elastase, collagenase, stromelysin), either directly by affecting transcription (Werb 1978, Frisch \& Ruley 1987), or indirectly by inhibiting interleukin-1 production (Butler et al. 1989). Interleukin-1 $\beta$ is a strong regulator of invasion. Its secretion is reduced upon GC treatment (Librach et al. 1994). It is unknown, however, if it is involved in TA-effect on invasion in JEG-3 cells.

The absence of correlation of TA effects on the invasion and those on proMMP-2 and proMMP-9 expression is in line with the complexity of mechanisms governing trophoblast invasion and may reflect GC effects on other invasion regulating systems such as the plasminogen activator inhibitor (Ma et al. 2002). Moreover, activity of MMP-2 is regulated by several mechanisms, including gene expression, modifications of the balance between inactive pro-enzyme and active enzyme and by inhibition of MMP-2 activity by naturally occurring tissue inhibitors of metalloproteinases (for review, Mauviel 1993, Ries \& Petrides 1995, Yu et al. 1996).

The experiments were carried out in the presence and absence of $10 \%$ serum. Both culture conditions allow studying the effect of external stimuli on the cells at different phases of the cell cycle. Whereas in the absence of FCS, cells become arrested in $\mathrm{G}_{0}$, presence of serum maintains the cells in the cell cycle. Serum completely changed TA effects on hCG- and MMP-2-secretion and on proliferation, but not on invasion. This suggests that TA effects on invasion are elicited through cell-signalling pathways that are not altered by FCS or some of its components such as cytokines and immune mediators. These can modulate GC-induced activity of the GC receptor (Arzt et al. 2000).

TA is not a substrate for $11 \beta$-HSD-2, and thus can bind to GC and mineralocorticoid receptor. The differences in receptor expression levels between BeWo and JEG-3 cells (Speeg \& Harrison, 1979) may explain quantitative differences among the cell lines, but are unlikely to account for the opposite reactions. The actions of steroid hormones not only depends on the presence of hormone receptors in the cytosol/nucleus and of hormone response elements on the promotor of target genes, but also requires the recruitment and coordinated action of co-activators/co-repressors (Katzenellenbogen et al. 1996). Differential endowment with these factors may be one of the reasons for the differential response of BeWo and JEG-3 to TA. Alternatively, the response of the cells on GC may also depend on their differentiation state. BeWo choriocarcinoma cells are regarded as poorly differentiated ones, whereas JEG-3 have a higher degree of differentiation, i.e. they contain several syncytial elements (Babalola et al. 1990, Aplin et al. 1992, Mitchell et al. 1995). Term trophoblasts that also contain a proportion of multi-nucleated syncytia in vitro responded differently to the GC than mononucleated first trimester cytotrophoblasts (Guller et al. 1994).

Collectively, TA, a synthetic GC, is able to influence proliferation and, to a lesser extent, invasion of choriocarcinoma cells that serve as models for human trophoblast. Although the effects induced by the GC depend on the cell line and on the presence of FCS, these data suggest that GC treatment in vivo may have the potential to adversely affect trophoblast development and differentiation. Therefore, we recommend that care must be exercised when women are given synthetic GCs during gestation. Further, investigations with trophoblast cells from different periods of gestation are necessary to identify how GC treatment affects the placenta in vivo. Our study is a first step to explore physiological processes during placental and trophoblast development that are influenced by GCs.

\section{Acknowledgements}

The authors are grateful to I Andiel, R Michelmaier and E Schmidt for their excellent technical assistance. The study was supported by grants 7620 and 8339 (to GD) from the Jubilee Fund of the Austrian National Bank, Vienna, and by a grant of the Franz-Lanyar-Stiftung of the Medical Faculty, KarlFranzens-University of Graz, Austria.

\section{References}

Albini A, Iwamoto Y, Kleinman HK, Martin GR, Aaronson SA, Kotzlowski JM \& McEwan RNA 1987 Rapid in vitro assay for quantitating the invasive potential of tumor cells. Cancer Research 47 3239-3245.

Albiston AL, Obeyesekere VR, Smith RE \& Krozowski ZS 1994 Cloning and tissue distribution of the human 11 beta-hydroxysteroid dehydrogenase type 2 enzyme. Molecular Cellular Endocrinology 105 R11-R17.

Aplin JD, Sattar A \& Mould AP 1992 Variant choriocarcinoma (BeWo) cells that differ in adhesion and migration on fibronectin display conversed patterns of integrin expression. Journal of Cell Science 103 435-444.

Arriza JL, Weinberger C, Cerelli G, Glazer TM, Handelin BL, Houseman DE \& Evans RM 1987 Cloning of human mineralocorticoid receptor complementary DNA: structural and functional kinship with the glucocorticoid receptor. Science 237 268-275. 
Arzt E, Kovalovsky D, Igaz LM, Costas M, Plazas P, Refojo D, PaezPereda M, Reul JM, Stalla G \& Holsboer F 2000 Functional cross-talk among cytokines T-cell receptor and glucocorticoid receptor transcriptional activity and action. Annals of the New York Academy of Sciences 917 672-677.

Babalola GO, Coutifaris C, Soto EA, Kliman HJ, Shuman H \& Strauss JF 3rd 1990 Aggregation of dispersed human cytotrophoblastic cells: Lessons relevant to the morphogenesis of the placenta. Developmental Biology 137 100-108.

Bischof P, Martellli M, Campana A, Itoh Y, Ogata Y \& Nagase H 1995 Importance of metalloproteinases (MMP) in human trophoblast invasion. Early Pregnancy Biology and Medicine 1 263-269.

Brown RW, Chapman KE, Kotelevtsev Y, Yau JL, Lindsay RS, Brett L, Leckie C, Murad P, Lyons V, Mullins JJ et al. 1996 Cloning and production of antisera to human placental 11 beta-hydroxysteroid dehydrogenase type 2. Biochemical Journal 313 1007-1017.

Butler LD, Layman NK, RiedI PE, Cain RL, Shellhaas J, Evans GF \& Zuckerman SH 1989 Neuroendocrine regulation of in vivo cytokine production and effects: I in vivo regulatory networks involving the neuroendocrine system interleukin-1 and tumor necrosis factoralpha. Neuroimmunology 24 143-153.

Cervar M, Puerstner P, Kainer F \& Desoye G 1996 Endothelin-1 stimulates the proliferation and invasion of first trimester trophoblastic cells in vitro-a possible role in the etiology of pre-eclampsia? Journal of Investigative Medicine 44 447-453.

Dancis J, Jansen V \& Levitz M 1980 Placental transfer of steroids: effect of binding to serum albumin and to placenta. American Journal of Physiology 238 E208-E213.

Diederich S, Hanke B, Oelkers W \& Bahr V 1997 Metabolism of dexamethasone in the human kidney: nicotinamide adenine dinucleotide-dependent 11 beta-reduction. Journal of Clinical Endocrinology and Metabolism 82 1598-1602.

Driver PM, Kilby MD, Bujalska I, Walker EA, Hewison M \& Stewart PM 2001 Expression of 11 beta-hydroxysteroid dehydrogenase isozymes and corticosteroid hormone receptors in primary cultures of human trophoblast and placental bed biopsies. Molecular Human Reproduction 7 357-363.

Dupont E, Rheaume E, Simard J, Luu-The V, Labrie F \& Pelletier G 1991 Ontogenesis of 3 beta-hydroxysteroid dehydrogenase/delta 5-delta 4 isomerase in the rat adrenal as revealed by immunocytochemistry and in situ hybridisation. Endocrinology 129 2687-2692.

Edwards CR, Benediktsson R, Lindsay RS \& SeckI JR 1993 Dysfunction of placental glucocorticoid barrier: link between fetal environment and adult hypertension? Lancet 341 355-357.

Falkenhain A, Loren TH, Behrendt U \& Lehmann L 1998 Dead cell estimation - a comparison of different methods, New Developments and New Applications in Animal Cell Technology.

Feinstein MB \& Schleimer RP 1999 Regulation of the action of hydrocortisone in airway epithelial cells by 11 beta-hydroxysteroid dehydrogenase. American Journal of Respiratory Cell Molecular Biology 21 403-408.

Fisher SJ, Cui TY, Zhang L, Hartman L, Grahl K, Zhang GY, Tarpey J \& Damsky CH 1989 Adhesive and degradative properties of human placental cytotrophoblast cells in vitro. Jorunal of Cell Biology 109 891-902.

Frisch SM \& Ruley HE 1987 Transcription from the stromelysin promoter is induced by interleukin-1 and repressed by dexamethasone. Journal of Biological Chemistry 262 16300-16304.

Fujimoto N, Hosokawa N, Iwata K, Shinya T, Okada Y \& Hayakawa T 1994 A one-step sandwich enzyme immunoassay for inactive precursor and complexed forms of human matrix metalloproteinase 9 (92 kDa gelatinase/type IV collagenase gelatinase B) using monoclonal antibodies. Clinica Chimica Acta 231 79-88.

Fujimoto N, Mouri N, Iwata K, Ohuchi E, Okada Y \& Hayakawa T 1993 A one-step sandwich enzyme immunoassay for human matrix metalloproteinase 2 (72-kDa gelatinase/type IV collagenase) using monoclonal antibodies. Clinica Chimica Acta 221 91-103.
Garvey D \& Scott J 1981 Placental and fetal contraindications of dexamethasone administration to pregnant rats. Experientia 37 757-759.

Genbacev O, Zhou Y, Ludlow JW \& Fisher SJ 1997 Regulation of human placental development by oxygen tension. Science $\mathbf{2 7 7}$ 1669-1672.

Gomez-Sanchez EP, Cox D, Foecking M, Ganjam V \& Gomez-Sanchez CE 199611 beta-hydroxysteroid dehydrogenases of the choriocarcinoma cell line JEG-3 and their inhibition by glycyrrhetinic acid and other natural substances. Steroids 61 110-115.

Graham CH, Connelly I, MacDougall JR, Kerbel RS, Stetler-Stevenson WG \& Lala PK 1994 Resistance of malignant trophoblast cells to both the anti-proliferative and anti-invasive effects of transforming growth factor-beta. Experimental Cell Research 214 93-99.

Graham CH, Hawley TS, Hawley RG, Mac Dougall JR, Kerbel RS, Khoo N \& Lala PK 1993 Establishment and characterization of first trimester human trophoblast cells with extended lifespan. Experimental Cell Reserach 206 204-211.

Grossmann C, Scholz T, Rochel M, Bumke-Vogt C, Oelkers W, Pfeiffer AF, Diederich S \& Bahr V 2004 Transactivation via the human glucocorticoid and mineralocorticoid receptor by therapeutically used steroids in CV-1 cells: a comparison of their glucocorticoid and mineralocorticoid properties. European Journal of Endocrinology 151 397-406.

Grummer R, Hohn HP, Mareel MM \& Denker HW 1994 Adhesion and invasion of three human choriocarcinoma cell lines into human endometrium in a three-dimensional organ culture system. Placenta 15 411-429.

Guller S, Markiewicz L, Wozniak R, Burnham JM, Wang EY, Kaplan P \& Lockwood CJ 1994 Developmental regulation of glucocorticoidmediated effects on extracellular matrix protein expression in the human placenta. Endocrinology 134 2064-2071.

Hahn T, Barth S, Graf R, Engelmann M, Beslagic D, Reul JM, Holsboer F, Dohr G \& Desoye G 1999 Placental glucose transporter expression is regulated by glucocorticoids. Journal of Clinical Endocrinology and Metabolism 84 1445-1452.

Hahn T, Graf R, Oney T \& Desoye G 1994 Effects of the synthetic glucocorticoid triamcinolone acetonide on vasoactive hydrolases of the human placenta in vitro. Placenta 15 377-388.

Hochberger A, Sibley C, Pixley M, Sadovsky Y, Strauss B \& Boime I 1991 Choriocarcinoma cells increase the number of differentiating human cytotrophoblasts through an in vitro interaction. Journal of Biological Chemistry 266 8517-8522.

Katz VL, Thorp JM Jr \& Bowes WA Jr 1990 Severe symmetric intrauterine growth retardation associated with the topical use of triamcinolone. American Journal of Obstetrics and Gynecology 162 396-397.

Katzenellenbogen JA, O'Malley BW \& Katzenellenbogen BS 1996 Tripartite steroid hormone receptor pharmacology: interaction with multiple effector sites as a basis for the cell- and promoter-specific action of these hormones. Molecular Endocrinology 10 119-131.

Krozowski Z, MaGuire JA, Stein-Oakley AN, Dowling J, Smith RE \& Andrews RK 1995 Immunohistochemical localization of the 11 betahydroxysteroid dehydrogenase type II enzyme in human kidney and placenta. Journal of Clinical Endocrinology and Metabolism 802203-802209.

Lageson JM, Spelsberg TC \& Coulam CB 1983 Glucocorticoid receptor in human placenta: studies of concentration and functional differences of preterm and term tissue. American Journal of Obstetrics and Gynecology 145 515-523.

Lajic S, Wedell A, Bui TH, Ritzen EM \& Holst M 1998 Long-term somatic follow-up of prenatally treated children with congenital adrenal hyperplasia. Journal of Clinical Endocrinology and Metabolism 83 3872-3880.

Librach CL, Feigenbaum SL, Bass KE, Cui TY, Verastas N, Sadovsky Y, Quigley JP, French DL \& Fisher SJ 1994 Interleukin-1 $\beta$ regulates human cytotrophoblast metalloproteinase activity and invasion in vitro. Journal of Biological Chemistry 269 17125-17131. 
Listwak SJ, Gold PW \& Whitfield HJ Jr 1996 The human mineralocorticoid receptor gene promoter: its structure and expression. Journal of Steroid Biochemistry and Molecular Biology 58 495-506.

Ma Y, Ryu JS, Dulay A, Segal M \& Guller S 2002 Regulation of plasminogen activator inhibitor (PAI-)-1 expression in a human trophoblast cell line by glucocorticoid (GC) and transforming growth factor (TGF)-beta. Placenta 23 727-734.

Mauschitz R, Cervar M, Hahn T, Purstner P \& Desoye G 2000 Selfregulation of the endothelin receptor system in choriocarcinoma cells. Biochimimica Biophysica Acta 1502 224-234.

Mauviel A 1993 Cytokine regulation of metalloproteinase gene expression. Journal of Cell Biochemistry 53 288-295.

Mitchell AM, Yap AS, Payne EJ, Manley SW \& Mortimer RH 1995 Characterization of cell polarity and epithelial junctions in the choricarcinoma cell line JAR. Placenta 16 31-39.

Mollmann HW, Barth J, Haack D, Gruener A, Stroband D, Gyselby G, Rohdewald P \& Derendorf H 1986 Comparative studies on the pharmacokinetics and duration of effect of intra-articular application of glucocorticoid crystal suspensions. Akta Rheumatologia 11 55-60.

Morrish DW, Dakour J \& Li H 1998 Functional regulation of human trophoblast differentiation. Journal of Reproductive Immunology 39 179-195.

Osborne CK, Monaco ME, Kahn CR, Huff K, Bronzert D \& Lippman ME 1979 Direct inhibition of growth and antagonism of insulin action by glucocorticoids in human breast cancer cells in culture. Cancer Reserach 39 2422-2428.

Ostensen M 2001 Drugs in pregnancy. Rheumatological disorders. Best Practice and Research Clinical Obstetrics and Gynaecology 15 953-969.

Pasqualini JR, Nguyen BL, Uhrich F, Wiqvist N \& Diczfalusi E 1970 Cortisol and cotisone metabolism in the human foeto-placental unit at midgestation. Journal of Steroid Biochemistry 1 209-219.

Reinisch JM, Simon NG, Karow WG \& Gandelman R 1978 Prenatal exposure to prednisone in humans and animals retards intrauterine growth. Science 202 436-438.

Ries C \& Petrides PE 1995 Cytokine regulation of matrix metalloproteinase activity and its regulatory dysfunction in disease. Biological Chemistry Hoppe Seyler 376 345-355.

Ringler GE, Kallen CB \& Strauss JF 1989 Regulation of human trophoblast function by glucocorticoids: dexamethason promotes increased secretion of chorionic gonadotropin. Endocrinology 124 1625-1631.

Robinson BG, Emanuel RL, Frim DM \& Majzoub JA 1988 Glucocorticoid stimulates expression of corticotropin-releasing hormone gene in human placenta. PNAS 85 5244-5248.

Sanchez I \& Dynlacht BD 2005 New insights into cyclins, CDKs and cell cycle control. Seminars in Cell \& Developmental Biology 16 311-321.

Schmidt S, Rainer J, Ploner C, Presul E, Riml S \& Kofler R 2004 Glucocorticoid-induced apoptosis and glucocorticoid resistance: molecular mechanisms and clinical relevance. Cell Death and Differentiation 11 (Supplement 1) S45-S55.

Schoof E, Girstl M, Frobenius W, Kirschbaum M, Repp R, Knerr I, Rascher W \& Dotsch J 2001 Course of placental 11beta-hydroxysteroid dehydrogenase type 2 and 15-hydroxyprostaglandin dehydrogenase mRNA expression during human gestation. European Journal of Endocrinology 145 187-192.

Seckl JR 1994 Glucocorticoids and small babies. Quarterly Journal of Medicine 87 259-262.

Seckl JR 1997 Glucocorticoids feto-placental 11 beta-hydroxysteroid dehydrogenase type 2 and the early life origins of adult disease. Steroids 62 89-94.

Seckl JR 2004 Prenatal glucocorticoids and long-term programming. European Journal of Endocrinology 151 (Suppl 3) U49-U62.

Simmer HH, Tulchinsky D, Gold EM, Frankland M, Greipel M \& Gold AS 1974 On the regulation of estrogen production by cortisol and ACTH in human pregnancy at term. American Journal of Obstetrics and Gynecology 119 283-296.

Sloboda DM, Challis JR, Moss TJ \& Newnham JP 2005 Synthetic glucocorticoids: antenatal administration and long-term implications. Current Pharmaceutical Design 11 1459-1472.

Speeg KV Jr \& Harrison RW 1979 The ontogeny of the human placental glucocorticoid receptor and inducibility of heat-stable alkaline phosphatase. Endocrinology 104 1364-1368.

Staun-Ram E, Goldman S, Gabarin D \& Shalev E 2004 Expression and importance of matrix metalloproteinase 2 and 9 (MMP-2 and -9) in human trophoblast invasion. Reproductive Biology and Endocrinology 259.

Stewart PM, Murry BA \& Mason JI 1994 Human kidney 11 betahydroxysteroid dehydrogenase is a high affinity nicotinamide adenine dinucleotide-dependent enzyme and differs from the cloned type I isoform. Journal of Clinical Endocrinology and Metabolism 79 480-484.

Taylor RN, Newman ED \& Chen S 1991 Forskolin and methotrexate induce an intermediate trophoblast phenotype in cultured human choriocarcinoma cells. American Journal of Obstetrics and Gynecology 164 204-210.

Trautman PD, Meyer-Bahlburg HF, Postelnek J \& New MI 1995 Effects of early prenatal dexamethasone on the cognitive and behavioral development of young children: results of a pilot study. Psychoneuroendocrinology 20 439-449.

Weiss U, Cervar M, Puerstner P, Schmut O, Haas J, Mauschitz R, Arikan G \& Desoy G 2001 Hyperglycaemia in vitro alters the proliferation and mitochondrial activity of the choriocarcinoma cell lines BeWo, JAR and JEG-3 as models for human first-trimester trophoblast. Diabetologia 44 209-219.

Werb Z 1978 Biochemical actions of glucocorticoids on macrophages in culture. Specific inhibition of elastase, collagenase and plasminogen activator secretion and effects on other metabolic functions. Journal of Experimental Medicine 147 1695-1712.

Yu AE, Hewitt RE, Kleiner DE \& Stetler-Stevenson WG 1996 Molecular regulation of cellular invasion-role of gelatinase A and TIMP-2. Biochemistry and Cellular Biology 74 823-831.

Received 22 September 2005

First decision 3 November 2005

Revised manuscript received 20 March 2006

Accepted 20 April 2006 